\title{
\|ARTYKULY
}

Przeglad SejMOWY

nr 2(157)/2020, s. 9-27; https://doi.org/10.31268/PS.2020.16

ANITA ADAMCZYK*

FUAD JOMMA**

\section{Prezydent w systemie konstytucyjnym Syrii}

Artykuł jest próbą ukazania pozycji ustrojowej prezydenta w Syrii oraz analizy uprawnień głowy państwa od konstytucji z 1930 r. po ujęcie tego zagadnienia w konstytucji z 2012 r. Badaniu poddano zagadnienia dotyczące sposobu wyboru głowy państwa, kompetencje w zakresie władzy wykonawczej, ustawodawczej i sądowniczej, które wyznaczają pozycję ustrojową prezydenta. W artykule postawiono tezę, że silna pozycja ustrojowa prezydenta Syrii miała związek z łamaniem zasady podziału władzy, ogromnym wpływem armii na życie polityczne i brakiem demokratycznych doświadczeń. Silna pozycja prezydenta znalazła swoje odbicie w konstytucji z 1973 r., kiedy prezydentem był Hafiz al-Asad. Stan ten trwa do dzisiaj mimo przyjęcia nowej konstytucji w 2012 r.

SŁowa KLuczowe: Syria, prezydent, konstytucja, państwa arabskie

\section{President in the constitutional system of Syria}

The article presents the political position of the President in Syria and analyzes powers of the head of state from the 1930 Constitution to including this issue in the 2012 Constitution. The study covers issues regarding the method of choosing the head of state and the competences in the area of executive, legislative and judicial power which determine the position of the President within the state system. It is argued that the strong political position of the Syrian President is related to the violation of the principle of separation of powers, enormous influence of the army on political life and a lack of democratic experience. The strong position of the President was manifested in the 1973 Constitution, when Hafiz al-Assad was the President. This continues to this day despite the adoption of the new Constitution in 2012.

KEY words: Syria, president, constitution, Arab states

* Prof. dr hab. Anita Adamczyk, Uniwersytet im. A. Mickiewicza, Wydział Nauk Politycznych i Dziennikarstwa, anita.adamczyk@amu.edu.pl, https://orcid.org/0000-0002-2851-0200

** Dr hab. Fuad Jomma, Uniwersytet Szczeciński, Instytut Nauk o Polityce i Bezpieczeństwie, fuad@gazeta.pl,https://orcid.org/0000-0002-7981-7114 


\section{Uwagi wstępne}

Systemy polityczne w państwach arabskich charakteryzują się koncentracją władzy w rękach jednej osoby lub w ramach jednego organu. Do tych państw należy Syria, w której wpływ na ustrój polityczny mieli francuscy mandatariusze, przynależność do szeroko pojętego narodu arabskiego, a przede wszystkim różnorodność religijna i etniczna społeczeństwa syryjskiego. Walka o władzę między sunnitami, alawitami i druzami, czego przejawem były częste zamachy stanu, była motorem zmian konstytucji, co z kolei rzutowało na pozycję prezydenta. Część syryjskich ustaw zasadniczych miała charakter przejściowy. Sytuacja ustabilizowała się dopiero po objęciu prezydentury przez Hafiza al-Asada w 1971 r. Należy także nadmienić, że od roku 1963 do roku 2011 w Syrii obowiązywał stan wyjątkowy, co wiązało się także z wprowadzaniem nadzwyczajnego ustawodawstwa. Stan wyjątkowy wpływał także na to, że władza wykonawcza uzyskała nieograniczone możliwości, jeśli chodzi o doprowadzenie do rządów autorytarnych, a nawet totalitarnych ${ }^{1}$.

Silna pozycja prezydenta w Syrii wynikała z braku tradycji demokracji. Miała też związek z religią, która wiązała władzę publiczną z władzą boską i potrzebą posiadania autorytetu. Do tego należy tez dodać niską świadomość polityczną obywateli, która wynikała m.in. z analfabetyzmu, oraz plemienny podział społeczeństwa, który wymusza odgórne posłuszeństwo władzy (przy czym solidarność wewnętrzna jest gwarantem trwałości politycznej). Ponadto w interesie prezydentów i ich otoczenia, rodziny, klanu, reprezentujących sunnitów, a potem alawitów leżało wzmocnienie władzy wykonawczej, ponieważ jej utrata oznaczała nie tylko niebyt polityczny, ale także społeczny. Koncentracja władzy miała więc związek z zapewnieniem elitom korzyści oraz ze strategią przetrwania. Odejście od rządów silnej ręki na rzecz demokracji wiązałoby się z utratą kontroli nad tym, co może się wydarzyć w sferze polityki. Sytuacja zewnętrzna - stan wojny z Izraelem - także wymuszała silną władzę wykonawczą, a skupienie władzy zapewniało decyzyjność w trudnych sytuacjach. Trwałość i ugruntowana pozycja władzy miały związek z nieobecnością opozycji i systemem monopartyjnym, czyli brakiem pluralizmu politycznego, szczególnie po $1963 \mathrm{r}$. Wzmocnieniu pozycji prezydenta i tym samym rządów autorytarnych sprzyjał także kryzys ekonomiczny w państwie.

Od 2011 r. Syria jest państwem objętym wojną domową, w którym tuż po wystąpieniach społecznych w ramach tzw. arabskiej wiosny przyjęto konstytucję $2012 \mathrm{r}$. Na czele państwa stoi Baszszar al-Asad, będący prezydentem od 2000 r. Syria jest przykładem państwa, w którym choć istnieje konstytucja odwołująca się do demokratycznych zasad, to jednak nie jest ona gwarantem demokratycznych rządów prawa w państwie. Panuje tam korupcja w sferze politycznej i gospodarczej, wolności obywatelskie nie są przestrzegane, a sądy straciły niezależność.

Wybory na urząd prezydenta w Syrii ${ }^{2}$ zawsze należały do ważnych wydarzeń politycznych z uwagi na jego silną pozycję w układzie ustrojowym. Kadencja prezydenta

${ }^{1}$ Więcej na ten temat, F. Jomma, Wplyw podziałów religijnych, narodowych i etnicznych na procesy polityczne w Syrii, Szczecin 2018.

2 Zgodnie z konstytucją z 1973 r. prezydent był wybierany w referendum. 
trwała pięć lat, a od 1973 r. została wydłużona o kolejne dwa lata. Specyfiką wczesnej fazy rozwoju systemu politycznego w Syrii były częste zmiany osób na stanowisku prezydenta, co wiązało się z przewrotami wojskowymi. Sytuacja ustabilizowała się dopiero od połowy 1963 r. W latach 1930-1945 przeważali prezydenci bezpartyjni (wyjątkami byli Haszim al-Atasi i Szukri al-Kuwatli, reprezentujący Blok Narodowy). Później, do 1958 r. prezydenci należeli do Syryjskiej Partii Socjal-Nacjonalistycznej czy Partii Narodowej. Charakterystyczne było również i to, że od 1963 r. urząd prezydenta piastowali wyłącznie członkowie partii al-Baas. Większość prezydentów Syrii wywodziła się z kręgów wojskowych. Zdarzało się także, że jednocześnie piastowali oni funkcje prezydenta i premiera, dotyczy to np. Husniego Az-Zaima, Adiba asz-Sziszakliego, Amina al-Hafiza czy Nur ad Dina al-Atasiego.

Niniejszy artykuł jest próbą ukazania pozycji ustrojowej prezydenta Syrii oraz analizy uprawnień głowy państwa od konstytucji z 1930 r. po ujęcie tego zagadnienia w ustawie zasadniczej z 2012 r. Artykuł obejmuje zatem okres Republiki Syryjskiej (1930-1958), Zjednoczonej Republiki Arabskiej, kiedy Syria połączyła się z Egiptem (1958-1961) oraz Syryjskiej Republiki Arabskiej (od 1961 r.). Eksploracji poddano zagadnienia dotyczące sposobu wyboru głowy państwa, kompetencje w zakresie władzy wykonawczej, ustawodawczej i sądowniczej, które wyznaczają pozycję ustrojową prezydenta. W artykule postawiono tezę, że silna pozycja ustrojowa prezydenta Syrii miała związek z łamaniem zasady podziału władzy, ogromnym wpływem armii na życie polityczne i tym samym brakiem doświadczeń demokratycznych. Większość konstytucji powstała po przewrotach wojskowych, co miało wpływ na umocnienie autokratyczno-demokratycznego ustroju państwa, w którym wprawdzie przewidziano instytucje demokratyczne, ale z uwagi na silną pozycję egzekutywy były one słabe. Panował tam system rządów, w którym jednostka lub niewielka grupa osób miała wpływ na rządzenie państwem, co wzmacniało zasadę, że zwycięzca bierze wszystko. Przy pisaniu artykułu niezbędne okazały się metody właściwe dla nauk historycznych, metoda decyzyjna, instytucjonalno-prawna oraz komparatystyczna. Artykuł powstał na bazie dokumentów źródłowych (konstytucje Syrii), opracowań arabskich oraz anglojęzycznych. W literaturze polskiej brakuje bowiem opracowań naukowych na temat omawianego zagadnienia.

\section{Konstytucje Syrii ${ }^{3}$}

W pierwszej syryjskiej konstytucji nie przewidziano instytucji prezydenta. Została ona opracowana w 1920 r. i nigdy nie weszła w życie, ponieważ obszar Syrii był terenem

${ }^{3}$ W tej części wykorzystano następujące konstytucje: Konstytucja Arabskiego Królestwa Syrii z 1920 r., >http://emediatc.com/PublicFiles/File/201920\%. pdf (Konstytucja Wielkiego Królestwa Syrii); Konstytucja państwa syryjskiego z 1930 r., <http://parlia ment.gov.sy>; Konstytucja Syrii z 1950 r., <http://dustour.org>; Konstytucja Syryjskiej Republiki Arabskiej z 1953 r.; Konstytucja Syryjskiej Republiki Arabskiej z 27 lutego 2012 r.; Konstytucja tymczasowa z 1969 r., konstytucja al-Baas, dostępne na stronie $<$ http://parliament.gov.sy>; Konstytucja Zjednoczonej Republiki Arabskiej z 1958 r.; Stała Konstytucja Syryjska z 1973 r., <http://emediatc.com>; konstytucja tymczasowa z 1964 r., <http://souri.net>, dostęp 12 VII 2019. 
mandatowym Francji. Władzę wykonawczą ulokowano wówczas w rękach monarchy i rządu ${ }^{4}$. Francuzi, pełniąc władzę w tej części świata, zostali zobowiązani na mocy art. 1 dokumentu o mandacie dla Syrii i Libanu, zatwierdzonego przez Radę Ligę Narodów w 1922 r., do ustanowienia w ciągu trzech lat ,prawa organicznego" dla Syrii ${ }^{5}$, które miało zostać opracowane w porozumieniu z lokalną władzą oraz uwzględniać prawa, interesy i życzenia mieszkańców tego obszaru.

Prace nad projektem konstytucji rozpoczęto dopiero w 1928 r. Osobą odpowiedzialną za jej przygotowanie był Fawzi al-Ghazzi ${ }^{6}$. Władze francuskie nie zgodziły się jednak na jej zatwierdzenie z uwagi na artykuły dotyczące suwerenności Syrii, ograniczające francuski mandat nad Syrią ${ }^{7}$. Ostatecznie projekt przyjęto w 1930 r. po dodaniu art. 116, dającego władzy mandatowej duże uprawnienia. Pod wieloma względami w projekcie nawiązywano do rozwiązań ustrojowych III Republiki Francuskiej ujętych w konstytucji z 1875 r. ${ }^{8}$ Podobieństwa dotyczyły sposobu wyboru prezydenta (bezwzględną większością głosów przez parlament) oraz jego uprawnień. Wśród prerogatyw zaczerpniętych z konstytucji francuskiej należy wymienić: prawo łaski, prawo amnestii jedynie zgodnie z odrębną ustawą, prawo inicjatywy ustawodawczej, zwoływanie nadzwyczajnych posiedzeń parlamentu, ogłaszanie ustawy w ciągu miesiąca od daty przekazania jej rządowi, prawo wydawania dekretów oraz odraczanie na miesiąc posiedzeń parlamentu (w porozumieniu z Radą Ministrów odpowiednio do postanowień syryjskiej konstytucji). Na mocy syryjskiej ustawy zasadniczej z 1930 r. podobnie jak we francuskiej - w razie wakatu urzędu prezydenta do czasu wyboru nowego kandydata funkcje prezydenta przejmowała Rada Ministrów. Ponadto zgodnie i z francuską, i z syryjską konstytucją prezydent był odpowiedzialny za zdradę stanu, a każdy wydany przez niego akt prawny wymagał kontrasygnaty odpowiedniego ministra. Różnice między tymi konstytucjami dotyczyły długości kadencji prezydenta i możliwości jego reelekcji (w Syrii kadencja trwała pięć lat bez możliwości ponownego wyboru, a we Francji dwa lata dłużej z prawem do reelekcji). Ponadto w konstytucji

${ }^{4}$ Przyjęcie konstytucji było następstwem ogłoszenia niepodległości i utworzenia Królestwa Wielkiej Syrii z królem Fajsalem na czele. Projekt ustawy zasadniczej przygotowała 20-osobowa grupa wyłoniona z członków Syryjskiego Kongresu Narodowego pod przewodnictwem H. al-Atasiego. Ustawa została przyjęta przez członków Kongresu 13 lipca 1920 r. Konstytucja Arabskiego Królestwa Syrii z $1920 \mathrm{r}$.

${ }^{5}$ French Mandate for Syria and the Lebanon, „The American Journal of International Law” t. 17, nr 3 , Supplement: Official Documents (Jul. 1923), s. 177-182, <http://www.ndu.edu.lb>, dostęp 22 VII 2019.

${ }^{6}$ Polityk syryjski, prawnik żyjący w latach 1891-1929. Przeciwnik mandatu francuskiego nad Syrią, uznawany za autora pierwszej republikańskiej konstytucji Syrii. Współzałożyciel partii o nazwie Blok Narodowy, członek parlamentu po wyborach w 1928 r. i Zgromadzenia Konstytucyjnego; vide S.M. Moubayed, Stell \& Silk. Men and Women Who Shaped Syria 1900-2000, Seattle 2006, s. 229.

${ }^{7}$ Władze francuskie nie wyrazily zgody na art. 73, 74, 75, 110 i 112. Al-dasatir al-mutaakiba fi suria: tahlil we mukarana [Kolejne konstytucje Syrii: analiza porównawcza - A.A. oraz F.J.], czerwiec 2017 r., IDRAK Centre for Studies \& Consultations, <https://idraksy.net>, dostęp 12 VII 2019. Więcej na ten temat: A.T. Fildis, The Troubles in Syria: Spawned by French Divide and Rule, „Middle East Policy Council” 2019, t. XVIII, nr 4, <https://www.mepc.org>, dostęp 12 VII 2019.

${ }^{8}$ Historia państwa i prawa. Wybór tekstów źródłowych, red. B. Lesiński, Poznań 1995, s. 224-227. 
syryjskiej z 1930 r. określono wiek kandydata na urząd prezydenta (35 lat) i jego religię (islam).

Ostatecznie pierwsza syryjska konstytucja została ogłoszona - przez Henriego Ponsota, Wysokiego Komisarza Francji - 14 maja, a opublikowana 22 maja 1930 r. Po dwóch latach została ona zawieszona z powodu kryzysu parlamentarnego9. Pod koniec 1936 r. przywrócono jej postanowienia, a następnie w lipcu 1939 r. komisarz Gabriel Puaux zawiesił konstytucję, rozwiązał parlament i wprowadził rządy bezpośrednie. W 1943 r. ponownie przywrócono postanowienia konstytucji z 1930 r. — po zniesieniu art. 116 i wprowadzeniu kilku poprawek ${ }^{10}$. W tym roku Syria ogłosiła swoją niepodległość, jednak dopiero 17 kwietnia 1946 r. wojska francuskie opuściły obszar państwa syryjskiego i tym samym państwo syryjskie uzyskało pełną suwerenność.

W czerwcu 1949 r. z inicjatywy Husniego Az-Zaima, który przejął władzę w wyniku przewrotu wojskowego, opracowano projekt świeckiej i demokratycznej konstytucji, której podstawę stanowił system parlamentarny. Następnie z inicjatywy Samiego al-Hinnawiego, który w sierpniu 1949 r. dokonał zamachu stanu, kontynuowano prace nad projektem konstytucji. Nowa konstytucja została ostatecznie przyjęta 5 września 1950 r. Nazwano ją „konstytucją niepodległości”, ponieważ została przygotowana przez demokratycznie wybrane Zgromadzenie Konstytucyjne w Syrii. Syryjska ustawa zasadnicza z 1950 r. była bardzo postępowa - na jej mocy przyznano prawa polityczne kobietom, co w tym regionie świata było rzadkością. Konstytucja obowiązywała tylko jeden rok, choć Syryjczycy dwukrotnie ją przywracali: w 1954 r. (konstytucję zawieszono w 1958 r.) oraz w 1962 r. (na rok). W 1953 r. ogłoszono, że znowelizowana konstytucja jest zgodna $\mathrm{z}$ postanowieniami ustawy zasadniczej z 1950 r. Konstytucja z 1953 r. była pierwszą konstytucją prezydencką z której usunięto przepisy dotyczące stanowiska premiera, a prezydentowi przekazano szerokie uprawnienia wykonawcze. Dokonano zmiany sposobu wyboru prezydenta. Zrezygnowano z wyboru głowy państwa przez parlament na rzecz wyborów bezpośrednich. Po zjednoczeniu Syrii z Egiptem w 1958 r. ogłoszono nową konstytucję tymczasową, której fragmenty zostały przeniesione z konstytucji egipskiej z 1954 r. Postanowienia konstytucji z 1958 r. obowiązywały do czasu secesji Syrii, czyli do 1961 r. Po wprowadzeniu stanu wyjątkowego w 1963 r. w Syrii obowiązywały konstytucje tymczasowe wydane w roku: $1964^{11}$, 1969 i 1971. Dopiero w 1973 r. przygotowano ustawę zasadniczą, która nie miała charakteru temporalnego. Została ona opracowana pod silnym wpływem Hafiza al-Asada i była pierwszą konstytucją arabską, w której przyjęto

${ }^{9}$ Po wyborach parlamentarnych w 1932 r. członkowie Izby Reprezentantów odmówili złożenia przysięgi lojalności wobec konstytucji z powodu art. 116; vide M. Kiwan, Sawabit we mutaghejerat al-dasatir As-surija min 1920 ila 1971, <http://www.alkhaleej.ae>, dostęp 12 VII 2019.

${ }_{10}$ Ibidem. Więcej o dziejach syryjskiego konstytucjonalizmu vide Tsasul tarihi li tatawir al-distor as-suri, The Arab Orient Center for Strategic and Civilization Studies London, 11.02.2013, <https:/www. asharqalarabi.org.uk>, dostęp 12 VII 2019.

${ }^{11}$ W konstytucji z 1964 r. nie przewidziano instytucji prezydenta. Władza wykonawcza należała wówczas do Rady Prezydenckiej (kolegialna głowa państwa) i Rady Ministrów; vide F. Jomma, Wpływ podziałów religijnych..., s. 295. 
socjalistyczno-nacjonalistyczne zasady określające jedność świata arabskiego ${ }^{12}$. Konstytucja ta obowiązywała do 2012 r. W tym czasie była trzykrotnie nowelizowana, a ostatnia zmiana z 2000 r. dotyczyła poprawki art. 83, którą obniżono wiek prezydenta z 40 do 34 lat, co było niezbędne do objęcia urzędu prezydenta przez Baszszara al-Asada, syna wcześniej zmarłego prezydenta Hafiza al-Asada ${ }^{13}$.

\section{Ograniczenia biernego prawa wyborczego na urząd prezydenta Syrii}

Wprowadzenie ograniczeń w zakresie biernego prawa wyborczego związane jest z wyborem odpowiednich osób na określone urzędy. Wśród najczęściej spotykanych ograniczeń należały: wiek, narodowość, kadencyjność, religia.

Zgodnie z konstytucjami syryjskimi wyróżniano aż trzy różne ograniczenia wiekowe obowiązujące kandydatów na ten urząd. I tak według pierwszej konstytucji z $1930 \mathrm{r}$. minimalna granica wieku wynosiła 35 lat (art. 68), a w ustawie zasadniczej z 1973 r., po nowelizacji w 2000 r., była niższa o rok (art. 83). Poza tymi wyjątkami najczęściej uprawionym wiekiem do kandydowania w wyborach na urząd głowy państwa było ukończenie 40. roku życia (art. 72 konstytucji z 1950 r., art. 82 konstytucji z 1953 r., art. 83 konstytucji z 1973 r. i art. 84 konstytucji z 2012 r.). Innym ograniczeniem był wymóg wyznawania islamu. Przewidziano to niemal we wszystkich konstytucjach syryjskich, poza tymczasowymi z roku 1958 i 1969.

W większości konstytucji nie zawarto wymogu określonej płci kandydata na prezydenta. Wyjątkami w tej kwestii były dwie konstytucje, w których sugerowano, że nie może to być kobieta. Pierwsza to konstytucja z 1953 r. (art. 82.2), w której expressis verbis ujęto, że niedopuszczalne jest nominowanie kobiet na urząd prezydenta. Druga to konstytucja z 2012 r. w której art. 84.4 stwierdzono, że kandydat na prezydenta nie może być mężem kobiety nieposiadającej obywatelstwa Syrii. Tym samym wskazano na płeć osoby ubiegającej się o fotel prezydencki.

Innym ograniczeniem zawartym w konstytucjach było posiadanie przez kandydata na urząd prezydenta obywatelstwa Syrii. Wprost do tego zagadnienia odniesiono się w konstytucji z 2012 r., w której za niezbędne uznano nie tylko posiadanie przez kandydata obywatelstwa syryjskiego, ale także zamieszkiwanie (pobyt stały) przed ubieganiem się o urząd głowy państwa na terenie Syrii przez co najmniej 10 lat bez przerwy (art. 84.5). Dotyczyło to także konstytucji z 1950 r. (art. 82.1). W ustawie zasadniczej z 1973 r. wskazano natomiast, że kandydat na prezydenta musi być syryjskim Arabem ${ }^{14}$

12 Świadczyła o tym treść niektórych artykułów zawartych w konstytucji z 1973 r., a mianowicie art. $1.3,8,13.1,21,23.1,84.1$.

${ }^{13}$ F. Jomma, Wplyw podziałów religijnych..., s. 361.

${ }_{14}$ Zgodnie z art. 3 dekretu z 1969 r. jest to m.in. każda osoba urodzona w kraju lub poza nim z ojca syryjskiego Araba; każda osoba urodzona z matki posiadającej obywatelstwo Syrii, której pochodzenie ojca nie jest potwierdzone; każda osoba, której rodzice są nieznani lub mają nieustalone obywatelstwo 
(art. 83). Na mocy konstytucji z 1973 i 2012 r. kandydat na urząd prezydenta musiał także posiadać pełnię praw obywatelskich i politycznych, co stwierdzono expressis verbis w artykułach 83 i 84.3. Ponadto w ostatniej ustawie zasadniczej z 2012 r. znalazł się przepis mówiący o tym, że kandydat na prezydenta nie może być skazany za przestępstwo (nawet jeśli został uniewinniony; art. 84.3).

Kolejnym ograniczeniem w zakresie biernego prawa wyborczego na urząd prezydenta Syrii była reelekcja. W konstytucjach syryjskich w różny sposób regulowano tę kwestię. Na przykład w konstytucjach z 1930 i 1950 r. w ogóle nie przewidziano reelekcji. Ustawodawca uznał jedynie, że ustępujący prezydent może zostać ponownie wybrany po upływie pięciu lat (art. 68 i art. 73). Natomiast zgodnie z konstytucją z 2012 r. umożliwiono jedną reelekcję prezydenta (art. 88), ale liczoną dopiero od wyborów w 2014 r. (art. 155), co oznacza, że obecny prezydent będzie mógł sprawować urząd prezydenta do 2028 r. (po pomyślnych dla niego wyborach), chyba że nastąpi nowelizacja konstytucji w tym zakresie lub zostanie przyjęta nowa ustawa zasadnicza. W konstytucjach z lat: 1953, 1958, 1969, 1973 nie regulowano tej kwestii.

Innym ograniczeniem w zakresie sprawowania urzędu prezydenta była bariera związana z łączeniem tej funkcji z innymi (incompatibilitas). Celem wprowadzenia tej zasady było podkreślenie wysokiej pozycji głowy państwa oraz podniesienie jej prestiżu. Incompatibilitas pozwala zapobiegać angażowania prezydenta w różne dziedziny aktywności, które mogłyby podważyć powagę jego urzędu ${ }^{15}$. Odniesienie do tej zasady można znaleźć w syryjskich ustawach zasadniczych z roku: 1930, 1950 i 1953, zgodnie z którymi dotyczyła ona zakazu łączenia urzędu prezydenta z mandatem parlamentarzysty (art. 69, art. 74 i art. 84.1). Poza niepołączalnością formalną w konstytucji z 1953 r. wprowadzono również zasadę niepołączalności materialnej, co oznaczało zakaz wykonywania przez prezydenta innej pracy w przemyśle, handlu czy administracji dla zysku (art. 84.2). Dotyczyło to także art. 45 tymczasowej konstytucji Zjednoczonej Republiki Arabskiej z 1958 r., w którym uznano, że głowa państwa podczas swojej kadencji nie może ,wykonywać wolnego zawodu, pracy komercyjnej, finansowej lub przemysłowej, kupować ani dzierżawić żadnej nieruchomości państwowej, wynajmować ani sprzedawać żadnej nieruchomości ze swojego majątku, ani też wystawiać jej pod zastaw”. Wskazanej zasady nie ujęto w konstytucjach z roku: 1930, 1969, 1973 i 2012.

Innym ograniczeniem w objęciu prezydentury było złożenie przysięgi. Wymóg ten został uregulowany w konstytucjach z: 1930 r. (art. 70), 1950 r. (art. 75), 1953 r. (art. 50), 1969 r. (art. 59), 1973 r. (art. 7) i 2012 r. (art. 90). Instytucja przysięgi to krótki tekst zawierający uroczyste i publiczne zobowiązanie prezydenta do wypełniania obowiązków wynikających z konstytucji, składane dla dobra ojczyzny i jego obywateli.

lub są bezpaństwowcami i zostali znalezieni w Syrii; każdy, kto urodził się w Syrii i w chwili urodzenia nie miał prawa do innego obywatelstwa. Dekret ustawodawczy 276 z 1969 r. o obywatelstwie syryjskiego Araba wraz z pouczeniem wykonawczym, <http://parliament.gov.sy/arabic/index>, dostęp 12 VII 2019.

15 T. Kowalczyk, Ograniczenia biernego prawa wyborczego na urząd Prezydenta RP, [w:] Wybory i pozycja ustrojowa prezydenta w wybranych państwach świata, red. R. Zych, Toruń 2011, s. 134; Polskie prawo konstytucyjne. Stan prawny na dzień 1 września 1997 r., red. W. Skrzydło, Lublin 1997, s. 305. 
Jest to przysięga polityczna, ponieważ dotyczy osoby pełniącej z mocy prawa funkcje państwowe. Konstytucje syryjskie nie zawierały odniesień expressis verbis do sytuacji, w której prezydent złamałby przysięgę. Złożenie jej — jak twierdzi P. Sarnecki - ma bowiem bardziej wymiar moralno-polityczny niż prawny ${ }^{16}$. Zgodnie z praktyką konstytucyjną w Syrii jej złożenie jest równoznaczne z objęciem przez daną osobę urzędu prezydenta. Dopiero wówczas prezydent może wykonywać swoje funkcje, w tym wydawać de facto akty prawne.

Analizując teksty przysięg składanych przez prezydentów Syrii, można zauważyć, że zawierały one odwołanie do religii, były zatem aktami ze sfery sacrum. Dotyczyło to konstytucji z roku: 1930, 1950, 1953, 1958, 1973 i 2012. Takiego odwołania nie było jedynie w konstytucji z 1969 r., w której prezydent przysięgał na „swój honor i wierzenia”. Podmiotem przysięgi był Wszechmogący Bóg (Allah). Odwołanie do Allaha skłania wiec do pytania o spójność konstytucji z przysięgą, ponieważ z jednej strony gwarantowano wolność sumienia i wyznania, a z drugiej wskazywano nadrzędność jednej religii nad innymi. Nie należy też zapominać o wymogu dotyczącym konkretnej religii wyznawanej przez prezydenta, czyli islamie. Ponadto przywołanie Allaha w przysiędze nie pozwalało na zachowanie przez prezydenta jako głowy państwa bezstronności wobec innych religii.

Jedynie w dwóch konstytucjach nawiązano w treści przysięgi do konieczności zachowania przez prezydenta integralności terytorialnej i niezależności państwa. Dotyczyło to ustaw zasadniczych z roku 1930 i 2012. Oznacza to, że były one wydawane w trudnym dla państwa okresie dziejowym, czyli w okresie mandatu francuskiego i początku konfliktu wewnętrznego. W konstytucji z 1930 r. uznano Syrię za niepodzielną jednostkę polityczną, której żadna część nie może zostać odłączona (art. 1 i 2). Natomiast w konstytucji z 2012 r. stwierdzono, że Syria jest niepodzielnym państwem i nie może zrzec się żadnej części swego terytorium (art. 1). W swoich przysięgach syryjscy prezydenci zobowiązywali się ponadto szanować konstytucję i prawa. Mieli stać w obronie „wolności ludu, ich interesów i majątku” (1950 r.), ,godności” (1953 r.), jak i „interesów ludu i bezpieczeństwa ojczyzny" (1969 r., 1973 r.). Prezydent wygłaszając przysięgę, zobowiązywał się wypełniać swoje obowiązki z honorem i szczerością oraz działać na rzecz osiągnięcia jedności narodu arabskiego (konstytucje z roku: 1950, 1953, 1973, 2012). Zgodnie z konstytucją z 1953 r. miał bronić systemu republikańskiego, a zgodnie z konstytucją 1973 r. pracować na rzecz socjalizmu.

\section{Wybór prezydenta}

W historii Syrii prezydent był wybierany zarówno przez parlament, jak i przez naród, co miało wpłynąć na wzmocnienie pozycji głowy państwa. Według pierwszej syryjskiej ustawy zasadniczej prezydenta wybierała Izba Reprezentantów w tajnym głosowaniu bezwzględną większością głosów. Jeśli się jednak okazało, że kandydat

${ }^{16}$ P. Sarnecki, Prezydent Rzeczypospolitej Polskiej. Komentarz do przepisów, Kraków 2000, s. 46. 
nie otrzymał wymaganego poparcia, to w trzeciej rundzie głosowania do jego wyboru wystarczyła większość względna (art. 68). Na mocy konstytucji z 1950 r. wyboru dokonywali również parlamentarzyści w głosowaniu tajnym. Kandydat na urząd prezydenta musiał jednak uzyskać poparcie $2 / 3$ głosów wszystkich członków izby. Gdyby nie zebrał tylu głosów, to w drugim głosowaniu wymagana była bezwzględna większość głosów, a w kolejnym wystarczyła większość względna (art. 71). Zmianę sposobu wyboru prezydenta wprowadzono w ustawie zasadniczej z 1953 r. — odtąd zgodnie $\mathrm{z}$ art. 81.1 wybory miały być czteroprzymiotnikowe, czyli powszechne, równe, tajne i bezpośrednie. Urząd obejmował kandydat, który otrzymał największą liczbę głosów wyborców (art. 81.3). Później ponownie powrócono do wyboru głowy państwa przez Zgromadzenie Ludowe, czyli parlament (art. 48 konstytucji z 1969 r.). Po kilku latach zrezygnowano $\mathrm{z}$ tego sposobu wyborów na rzecz wyborów bezpośrednich — kandydat na prezydenta musiał jednak uzyskać rekomendację krajowego kierownictwa partii al-Baas, a następnie zostać zaakceptowany przez Zgromadzenie Ludowe (art. 84.1 konstytucji z 1973 r.). Kandydat musiał uzyskać w referendum (wyborach) bezwzględną większość głosów. Jeśli jej nie uzyskał, to Zgromadzenie zgłaszało nowego kandydata, którego kandydatura była poddawana referendum w ciągu miesiąca od ogłoszenia wyniku pierwszego referendum (art. 84.4).

Przepisy dotyczące wyborów bezpośrednich utrzymano w konstytucji z 2012 r. Od zwycięzcy wymagano uzyskania bezwzględnej większości głosów. W sytuacji, gdy żaden z kandydatów nie przekroczyłby tego pułapu, przewidziano drugą turę wyborów między dwoma osobami, które osiągnęły największe poparcie (art. 86.2). Obecnie kandydata na prezydenta zgłasza Zgromadzenie Ludowe. Musi on uzyskać poparcie co najmniej 35 członków Zgromadzenia (przy czym jeden parlamentarzysta może oddać swój głos poparcia tylko raz). Jeśli warunki do kandydowania spełnia tylko jedna osoba, to przewodniczący parlamentu ma obowiązek wezwać inne osoby do zgłaszania kandydatury na urząd prezydenta (art. 85). Zgłoszenie kandydata bada Najwyższy Sąd Konstytucyjny, który rozpatruje też protesty wyborcze (art. 89). W konstytucji tymczasowej Zjednoczonej Republiki Arabskiej z 1958 r. w ogóle nie ujęto zagadnienia wyboru prezydenta.

W syryjskich konstytucjach nie poruszano kwestii apolityczności prezydenta. Jedynie w ustawie zasadniczej z 1973 r. jednoznacznie zasugerowano, że kandydat na ten urząd musi mieć poparcie partii al-Baas, co może wskazywać na jego przynależność do tego ugrupowania. Taka formuła naruszała zasadę neutralności głowy państwa.

\section{Odpowiedzialność prezydenta}

Zasada odpowiedzialności konstytucyjnej prezydenta została zapisana już w pierwszej konstytucji syryjskiej. Odnosił się do niej art. 82 konstytucji z 1930 r., zgodnie z którym prezydent był odpowiedzialny za naruszenie konstytucji i zdradę stanu. W pierwszej ustawie zasadniczej ustanowiono także, że odpowiedzialność za przestępstwa ogólne 
będzie regulowana w ustawodawstwie zwykłym (art. 82). W przypadku wymienionych w przepisie przestępstw o postawieniu prezydenta w stan oskarżenia mieli decydować parlamentarzyści większością 2/3 głosów (art. 82). Orzeczenie wydawał Sąd Najwyższy, a do czasu jego opublikowania prezydent pozostawał zawieszony w pełnieniu swoich obowiązków. Podobnie kwestię tę uregulowano w konstytucjach z 1950 r. i 1953 r. $\mathrm{z}$ tą jednak różnicą, że postawienie prezydenta $\mathrm{w}$ stan oskarżenia musiała poprzeć 1/4 członków Izby Reprezentantów (art. 86 konstytucji z 1950 r. i art. 87 i 88 konstytucji z 1953 r.). Natomiast zgodnie z konstytucją z roku 1973 i 2012 prezydent ponosił odpowiedzialność jedynie za zdradę stanu (art. 91 konstytucji z 1973 r. i art. 117 konstytucji z 2012 r.). Wniosek o wystąpienie z aktem oskarżenia wymagał poparcia co najmniej 1/3 liczby członków Zgromadzenia Ludowego, a decyzję przyjmowano większością 2/3 głosów podczas tajnej sesji parlamentu. Kompetentnym sądem w tej sprawie był Najwyższy Sąd Konstytucyjny, złożony z pięciu członków, z których jednego wyznaczał prezydent (art. 139), a od 2012 r. Najwyższy Sąd Konstytucyjny (art. 117). Odpowiedzialności prezydenta nie ujęto w konstytucjach z roku 1958 i 1969.

Należy jednocześnie nadmienić, że syryjscy prezydenci nie ponosili odpowiedzialności politycznej za swoje czynności urzędowe. Akty prawne prezydenta musiały uzyskać kontrasygnatę odpowiedniego ministra i premiera (konstytucja z 1950 r.) lub tylko ministra (konstytucje z roku 1930 i 1953). Instytucja kontrasygnaty wymuszała zatem współpracę prezydenta z rządem i zobowiązywała rząd do realizacji podpisanego aktu. Ponadto kontrasygnata umożliwiała odróżnienie sfery aktywności prezydenta, która wymagała współpracy z rządem, od tej, w której miał samodzielne kompetencje, jak np. powołanie danej osoby na stanowisko premiera lub jej odwołanie (art. 76 konstytucji z 1930 r. i art. 79 konstytucji z 1950 r.). Do zagadnienia kontrasygnaty nie odniesiono się natomiast w: konstytucji tymczasowej Zjednoczonej Republiki Arabskiej z 1958 r., konstytucji tymczasowej z 1969 r. oraz ustawach zasadniczych z roku 1973 i 2012.

\section{Wygaśnięcie mandatu prezydenta i jego zastępstwo}

W prawie konstytucyjnym Syrii przewidziano kilka powodów wygaśnięcia mandatu głowy państwa. Jednym z nich jest zakończenie kadencji prezydenta zgodnie z konstytucją. Do innych przyczyn zalicza się: śmierć głowy państwa, zrzeczenie się sprawowanego urzędu, skazanie prawomocnym orzeczeniem Sądu Najwyższego (np. Najwyższego Sądu Konstytucyjnego) za zdradę stanu czy naruszenie konstytucji. W przypadku zrzeczenia się urzędu, zgodnie z art. 86 konstytucji z 1953 r., prezydent informował lud w liście publikowanym przez przewodniczącego parlamentu. W podobny sposób ujęto to w konstytucjach z roku 1973 (art. 87) oraz 2012 (art. 94).

W przypadku trwałej niezdolności prezydenta do pracy — z powodu śmierci, zrzeczenia się urzędu, odwołania zgodnie z wyrokiem Sądu Najwyższego — jego funkcje przejmował przewodniczący parlamentu (art. 89.2 konstytucji z 1953 r.). Podobnie 
uregulowano tę kwestię w art. 60 konstytucji z 1969 r. Zadania prezydenta przechodziły na przewodniczącego parlamentu, po zrzeczeniu się przez przewodniczącego jego funkcji. Jeśli jednak parlament pozostawał w tym czasie rozwiązany lub pozostało mu mniej niż dwa miesiące do końca kadencji, uprawnienia głowy państwa przejmował premier aż do zwołania nowego Zgromadzenia Ludowego. Od 1973 r. prezydenta mógł zastąpić jeden z wiceprezydentów (art. 88). W sytuacji, gdy nie było wiceprezydentów, zadania przejmował premier do czasu przeprowadzenia referendum w sprawie wyboru prezydenta w ciągu 90 dni (art. 89). Podobnie tę kwestię rozwiązano w konstytucji z 2012 r. (art. 93.1 i 2).

Poza przeszkodami, które trwale i nieodwracalnie uniemożliwiają sprawowanie urzędu głowy państwa, wyróżnia się także okoliczności tymczasowe będące przeszkodą w sprawowaniu urzędu, kiedy prezydent mógł zostać zastąpiony w pełnieniu swoich zadań. I tak np. zgodnie z konstytucją z 1930 r. prezydenta mógł zastąpić premier (art. 84), a zgodnie z art. 88.1 konstytucji z 1950 r. i art. 89 konstytucji z 1953 r. przewodniczący parlamentu. Dotyczyło to takich sytuacji, jak: choroba, czasowa nieobecność w państwie, skierowanie sprawy przeciwko prezydentowi do Sądu Najwyższego lub z innych powodów. Zgodnie z konstytucją z 1973 r. funkcje prezydenta przejmował wiceprezydent (art. 86). Podobnie jest od czasu wejścia w życie postanowień konstytucji z 2012 r. (art. 92).

\section{Kompetencje prezydenta Syrii do 2012 r.}

Konstytucyjny zakres kompetencji głowy państwa jest funkcją czynników politycznych i ustrojowych, które kształtują jego pozycję w systemie ustrojowym państwa. Ich klasyfikacja pozwala na wyróżnienie kompetencji w zakresie stosunków międzynarodowych i wewnętrznych. W ramach pierwszej z nich prezydent, reprezentując lud, zawiera i podpisuje w jego imieniu traktaty międzynarodowe. Zgodnie z konstytucją z $1930 \mathrm{r}$. umowy dotyczące bezpieczeństwa państwa, finansów, umowy handlowe i inne traktaty, których nie można było wypowiedzieć, pod koniec każdego roku wymagały dodatkowo zgody parlamentu (art. 74). Natomiast według art. 77.2 ustawy zasadniczej z $1950 \mathrm{r}$. i art. 54.5 konstytucji z 1969 r. prezydent podpisywał traktaty po ich zatwierdzeniu przez parlament. Na mocy aktu z 1958 r. prezydent jedynie informował parlament o zawarciu traktatu (art. 56). Wyjątkiem od tej reguły były umowy dotyczące pokoju, sojuszy, handlu, żeglugi oraz traktaty zmieniające granice państwa, związane z suwerennością państwa - one wymagały zgody parlamentu. Do uprawnień prezydenta w zakresie spraw międzynarodowych należało także mianowanie szefów misji dyplomatycznych poza granicami państwa, jak i akredytowanie szefów misji dyplomatycznych w Syrii (art. 75 konstytucji z 1930 r., art. 77.3 konstytucji z 1950 r., art. 92.4 konstytucji z 1953 r. i art. 102 konstytucji z 1973 r.).

Do kompetencji prezydenta w zakresie spraw wewnętrznych należały uprawnienia związane ze zwierzchnictwem nad siłami zbrojnymi, z obronnością i bezpieczeństwem 
w okresie wojny i pokoju. Prezydent zgodnie z konstytucjami był najwyższym dowódcą sił zbrojnych (art. 55 konstytucji z 1958 r., art. 103 konstytucji z 1973 r., art. 83 konstytucji z 1950 r., art. 91 konstytucji z 1953 r.) i stał na czele Rady Obrony Narodowej (art. 83 konstytucji z 1950 r., art. 91 konstytucji z 1953 r.). Ponadto wypowiadał wojnę. Na podstawie ustaw zasadniczych z lat pięćdziesiątych XX w. czynił to na podstawie decyzji Rady Ministrów po konsultacji z Radą Obrony Narodowej i zatwierdzeniu decyzji przez parlament (art. 82 konstytucji z 1950 r., art. 92.5 konstytucji z 1953 r. z pominięciem decyzji Rady Ministrów). Podjęcie działań obronnych na mocy art. 92.6 konstytucji z 1953 r. wymagało konsultacji z Radą Obrony Narodowej, a zgodnie z art. 100 konstytucji z 1973 r. ogłoszenie wojny wymagało zgody Zgromadzenia Ludowego. Prawo do wypowiadania wojny dano prezydentowi także w konstytucji tymczasowej z 1969 r. (art. 54.4).

Prezydent Syrii w stanach zagrożenia państwa mógł ogłosić stan wyjątkowy. Zgodnie z konstytucją z 1930 r. mógł to uczynić na wniosek Rady Ministrów i pod warunkiem poinformowania o tym parlamentu (art. 112), a zgodnie z konstytucją z $1953 \mathrm{r}$. za zgodą parlamentu na czas oznaczony, czyli nie dłużej niż miesiąc (art. 92.8). Stan wyjątkowy był ogłaszany w przypadku zagrożenia wojną lub wojny, jak i w przypadku wewnętrznych zakłóceń i klęsk żywiołowych (art. 92). Prawo do ogłaszania stanu wyjątkowego przez prezydenta zawarto również w konstytucjach z roku 1958 (art. 57) i 1973 (art. 101).

Do uprawnień prezydenta, zgodnie z konstytucją z 1953 r., należało także ogłaszanie ogólnej lub częściowej mobilizacji (art. 92). Decyzja o mobilizacji, po wejściu w życie konstytucji z 1969 r., wymagała zatwierdzenia przez Radę Ministrów i Zgromadzenie Ludowe (art. 54.4 konstytucji z 1969 r.), a po 1973 r. tylko Zgromadzenia Ludowego (art. 100). Do uprawnień prezydenta w zakresie obronności nie nawiązywano w konstytucji z $1930 \mathrm{r}$.

Do innych kompetencji głowy państwa w stosunkach wewnętrznych należało także: prawo amnestii ogólnej (konstytucje z roku: 1930, 1950 i 1969), amnestii specjalnej (konstytucje z roku: 1950, 1969, 1973 i 2012), prawo nadawania orderów i odznaczeń (poza konstytucjami z roku: 1930, 1950 i 1953). Wskazane uprawnienia nie zostały ujęte jedynie w konstytucji z $1958 \mathrm{r}$.

Kompetencje prezydenta Syrii wobec parlamentu, rządu i władzy sądowniczej wskazywały na jego pozycję ustrojową oraz określały wzajemne relacje między nim a tymi organami. Ustawodawca syryjski wyposażył prezydenta w uprawnienia, dzięki którym mógł on wpływać na tryb pracy parlamentu.

Prezydent w ramach swoich kompetencji mógł:

1. Zwołać nadzwyczajną sesję parlamentu (art. 45 konstytucji z 1930 r., art. 108 konstytucji z 1973 r.).

2. Rozwiązać parlament (art. 45 konstytucji z 1930 r., art. 85 konstytucji z 1950 r., art. 38 konstytucji z 1958 r., art. 55 konstytucji z 1969 r. art. 107.1 konstytucji z 1973 r.) nie więcej niż jeden raz z tego samego powodu (art. 45 konstytucji z 1930 r., art. 107.2 konstytucji z 1973 r.). 
3. Odroczyć posiedzenie parlamentu, w porozumieniu z Radą Ministrów, ale nie więcej niż dwa razy w ciągu tej samej sesji (art. 81 konstytucji z 1930 r.).

4. Utajnić posiedzenie parlament na swój wniosek (art. 59.2 konstytucji z 1953 r.).

Na mocy konstytucji z 1953 r. prezydent mógł ponadto wydłużyć kadencję parlamentu. Proponował to na podstawie ustawy, do przegłosowania której konieczna była większość bezwzględna (art. 42.1). Natomiast konstytucją z 1958 r. dano prezydentowi uprawnienie do zwołania i odraczania sesji Rady Narodu (parlamentu) (art. 17). Decyzja o wyborze i liczbie członków Rady należała do głowy państwa (art. 13).

Ponadto zgodnie z niektórymi syryjskimi konstytucjami pozwalano prezydentowi wpływać na aktywność prawotwórczą parlamentu. Prezydent realizował ją poprzez prawo inicjatywy ustawodawczej (art. 32 konstytucji z 1930 r., art. 50 konstytucji z 1958 r., art. 110 konstytucji z 1973 r.), prawo do ogłaszania ustawy (art. 79 konstytucji z 1930 r., art. 61 konstytucji z 1950 r., art. 73 konstytucji z 1953 r., art. 50 konstytucji z 1958 r., art. 98 konstytucji z 1973 r.), prawo do ponownego rozpatrzenia ustawy (art. 80 konstytucji z 1930 r., art. 62 konstytucji z 1950 r., art. 74 konstytucji z 1953 r., art. 50 konstytucji z 1958 r.) i prawo weta wobec ustaw (art. 50 konstytucji z 1958 r., art. 98 konstytucji z 1973 r.).

Dzięki swoim kompetencjom prezydent mógł wpływać na rząd poprzez powoływanie jego członków i oddziaływanie na politykę. Analiza konstytucyjnych rozwiązań w Syrii pozwala wyróżnić kilka uprawnień związanych ze wskazanymi zagadnieniami. I tak zgodnie z konstytucją z 1930 i 1969 r. prezydent desygnował prezesa Rady Ministrów, ministrów zaproponowanych przez premiera i przyjmował ich dymisje (w kolejności art. 75, art. 54.1). Podobnie w ustawach zasadniczych z roku: 1953, 1958, 1973 ustalono, że prezydent w ramach swych uprawnień powołuje i odwołuje ministrów (w kolejności: art. 94.2, art. 47, art. 95).

Prezydent mógł wypełniać swoje zadania również w zakresie polityki rządu. Zgodnie z art. 78 konstytucji z 1950 r. mógł zwołać posiedzenie Rady Ministrów pod swoim przewodnictwem. Dotyczyło to także rozwiązań zaproponowanych w konstytucjach z roku: 1969 (art. 57) i 1973 (art. 97). Zgodnie z konstytucją z 1969 r. premier i ministrowie przed objęciem swoich obowiązków składali przysięgę przed prezydentem (art. 66). Dotyczyło to także ustawy zasadniczej z 1973 r. (art. 116). Zgodnie z konstytucjami z roku 1953 i 1973 ministrowie ponosili przed nim odpowiedzialność (art. 97.2) oraz premier na mocy ustawy zasadniczej z 1973 r. (art. 117). Zgodnie z wcześniejszymi konstytucjami odpowiadali oni politycznie przed parlamentem. Prezydent mógł postawić ministra przed sądem za popełnienie przestępstwa (art. 123 konstytucji z 1973 r.).

Prezydent Syrii miał także wpływ na władzę sądowniczą. Początkowo miał jedynie prawo mianowania sędziów (art. 75 konstytucji z 1930 r.), ale w kolejnych ustawach zasadniczych rozszerzono jego kompetencje w tym zakresie. Mógł np. przedkładać parlamentowi listę kandydatów (14 osób) do Sądu Najwyższego, spośród których parlament wybierał siedem osób (art. 116.1 konstytucji z 1950 r.) lub mianować za zgodą parlamentu przewodniczącego i członków Sądu Najwyższego (art. 114.1 konstytucji z 1953 r.). 
Zgodnie z syryjskimi konstytucjami prezydenta wyposażono także w uprawnienia budżetowe i inne związane z finansami państwa. Zgodnie z konstytucją z 1930 r., jeśli projekt budżetu nie został przyjęty na październikowej sesji parlamentu, prezydent miał prawo zwołania sesji nadzwyczajnej w celu kontynuowania dyskusji nad budżetem (art. 102). Jeśli wtedy także nie udało się przyjąć budżetu, prezydent na mocy dekretu przyjętego za zgodą Rady Ministrów przyjmował projekt budżetu w formie przedstawionej pierwotnie parlamentowi (art. 102). W ramach innych uprawnień w zakresie finansów państwa prezydent mógł, za zgodą Rady Ministrów, podjąć decyzję (w formie dekretu) o zaciągnięciu kredytu nadzwyczajnego czy dokonać przesunięć w budżecie (konstytucja z 1930 r.). Kredyt nie mógł być wyższy niż 2 tys. funtów syryjskich (art. 101). Natomiast zgodnie z konstytucjami z roku: 1950, 1969, 1973 prezydent nie miał uprawnień budżetowych. Jedynie w ustawie zasadniczej z $1953 \mathrm{r}$. prezydent otrzymał kompetencje do wydawania ustaw finansowych mających na celu zniesienie, obniżenie podatków czy zwolnienie z nich, jak i przeznaczanie części budżetu państwa na konkretne projekty (art. 66.2). Prezydent przedkładał parlamentowi projekt budżetu ogólnego, a ten go zatwierdzał (art. 67). Do kompetencji prezydenta na podstawie tej konstytucji należało także przesyłanie do parlamentu oświadczenia o sytuacji finansowej państwa przynajmniej raz w roku (art. 69).

Prezydent w ramach kompetencji ustrojowych miał prawo dokonywania zmian w konstytucji, które ulegało modyfikacji w kolejnych ustawach zasadniczych. I tak np. zgodnie z konstytucją z 1930 r. głowa państwa mogła jedynie wnioskować do parlamentu o nowelizację ustawy zasadniczej (art. 108). Na mocy art. 155 konstytucji z 1950 r. prezydent za zgodą Rady Ministrów i parlamentarzystów mógł domagać się nowelizacji konstytucji, ale dopiero po dwóch latach od jej wejścia w życie (art. 156). Natomiast zgodnie z konstytucją z 1953 r. prezydent mógł wnioskować o zmianę konstytucji również po upływie dwóch lat od dnia jej wejścia w życie (art. 121, 122) już tylko za zgodą członków parlamentu. Zagadnienia zmiany konstytucji nie ujęto w ustawie zasadniczej z 1958 r., a zgodnie z konstytucją z 1969 r. pozbawiono prezydenta możliwości wpływania na kształt konstytucji, przekazując to uprawnienie parlamentowi (art. 76). Po wejściu w życie konstytucji z 1973 r. prezydent mógł samodzielnie zaproponować nowelizację konstytucji (art. 149.1).

Prezydent rządził za pomocą dekretów. Wydawał je w celu powoływania urzędników (art. 80 konstytucji z 1950 r., art. 92.3 konstytucji z 1953 r.), sędziów czy w sprawach organizacyjnych (art. 80 konstytucji z 1950 r.). Dotyczyło to także dekretów wydawanych za zgodą Rady Ministrów w sprawie przepisów niezbędnych do wprowadzenia w życie ustaw (art. 95 konstytucji z 1950 r.). Prezydent w trakcie obowiązywania konstytucji z $1953 \mathrm{r}$. do czasu wyboru parlamentu mógł rządzić na podstawie dekretów ustawodawczych w sprawach niezbędnych do prowadzenia spraw w państwie, w tym prawa wyborczego w celu wyboru parlamentu (art. 124.1 i 124.2). Ustawą zasadniczą z 1958 r. dano prezydentowi uprawnienia do wydawania dowolnego ustawodawstwa lub decyzji należących do kompetencji Rady Narodu (parlamentu), w czasie gdy ta nie obradowała. Po jej zwołaniu akty te były przedstawiane Radzie 
do akceptacji (art. 53). Prezydent mógł także samodzielnie wydawać decyzje w celu „uporządkowania interesów publicznych i nadzorowania administracji” (art. 54). Uprawnienia prezydenta do stanowienia prawa między sesjami parlamentu utrzymano w konstytucji z 1973 r. pod warunkiem przedstawienia ich do akceptacji na pierwszym posiedzeniu Zgromadzenia Ludowego (art. 111.1). Podobnie jak w konstytucji z 1958 r. prezydent mógł stanowić prawo podczas sesji parlamentu, jeśli wymagał tego interes narodowy i bezpieczeństwo narodowe. W obu jednak przypadkach prawo to mogło zostać zmienione lub uchylone większością głosów 2/3 członków uczestniczących w posiedzeniu pod warunkiem, że nie była ona mniejsza niż większość bezwzględna członków parlamentu (art. 111.3). Nie dotyczyło to jednak ustawodawstwa przyjętego przez prezydenta między kadencjami parlamentu (art. 111.4).

\section{Pozycja ustrojowa prezydenta w konstytucji Syrii z 2012 r.}

W konstytucji Syrii z 2012 r. nie odwołano się expressis verbis do zasady podziału władzy, jak jest np. w art. 10 Konstytucji RP. W części III syryjskiej konstytucji, zatytułowanej „Władze państwowe”, uregulowano kwestie dotyczące władzy ustawodawczej (rozdział I), wykonawczej (rozdział II) i sądowniczej (rozdział III). Formalna systematyka konstytucji w tym fragmencie mogłaby sugerować ulokowanie prezydenta w konstytucyjnym systemie organów państwowych, ale byłaby to mylna sugestia. W długiej preambule stwierdzono m.in., że Syria wraz z jej mieszkańcami i instytucjami państwowymi od początku XXI w. znalazły się w trudnej sytuacji zagrażającej jej suwerenności, co skłoniło ustawodawcę do przyjęcia nowej konstytucji wzmacniającej rządy prawa. Opracowanie nowego projektu ustawy zasadniczej miało uspokoić nastroje społeczne. Obywatele Syrii domagali się bowiem od prezydenta przede wszystkim reform politycznych związanych z wprowadzeniem wolności i praw obywatelskich, pluralizmu politycznego, uwolnienia więźniów politycznych oraz reform ekonomicznych i społecznych.

Zgodnie z obowiązującą w Syrii konstytucją do prezydenta, obok premiera, należy władza wykonawcza, którą ma sprawować w imieniu narodu (art. 83). Ma on gwarantować przestrzeganie konstytucji, należyte funkcjonowanie władz państwowych, ochronę jedności narodowej i bytu państwowego (art. 96). Prezydent przedstawia założenia polityki publicznej państwa i wraz z Radą Ministrów nadzoruje wcielanie ich w życie (art. 98). Za swoją działalność nie ponosi odpowiedzialności, z wyjątkiem zarzutu o zdradę stanu (art. 117). Część swoich uprawnień może scedować na jednego lub więcej zastępców, którzy składają przed nim przysięgę konstytucyjną (art. 91).

Wśród kompetencji prezydenta należy wymienić:

1. Uprawnienia w zakresie spraw międzynarodowych — prezydent zawiera i wypowiada umowy międzynarodowe oraz zatwierdza szefów misji dyplomatycznych do innych państw i akredytuje szefów misji dyplomatycznych w Syrii (art. 104, 107). 
2. Uprawnienia w zakresie obronności państwa - do prezydenta należy naczelne dowództwo armii i sił zbrojnych, wypowiedzenie wojny i zawarcie pokoju, ogłoszenie powszechnej mobilizacji po uzyskaniu zgody parlamentu, wprowadzenie i zakonczenie stanu wyjątkowego, mianowanie urzędników wojskowych (art. 102, 103, 105, 106). Ponadto zgodnie $\mathrm{z}$ art. 114 prezydent ma szczególne uprawnienia do podjęcia „wymaganych przez okoliczności procedur”, kiedy zagrożona jest jedność narodowa, bezpieczeństwo i integralność terytorialna państwa.

3. Uprawnienia ustawodawcze - prawo nowelizacji konstytucji, wydawanie dekretów, decyzji i rozkazów w granicach określonych prawem, prawo inicjatywy ustawodawczej, uprawnienie do stanowienia prawa, kiedy parlament nie obraduje, uległ rozwiązaniu i kiedy zachodzi wyższa konieczność, pod warunkiem akceptacji przez Zgromadzenie Ludowe na jego pierwszym posiedzeniu (art. 101, 112, 113, 150).

4. Uprawnienia w stosunku do parlamentu - prezydent zwołuje na podstawie dekretu pierwsze posiedzenie parlamentu, zatwierdza prawa uchwalone przez Zgromadzenie Ludowe. Ma także w stosunku do nich prawo weta, ale jeśli parlament po raz drugi większością 2/3 głosów przyjmie dane prawo, prezydent musi je zatwierdzić. Ponadto prezydent ma prawo przemawiania przed parlamentem, może go rozwiązać, ale nie więcej niż jeden raz z tego samego powodu (art. 64.1, 100, 110, 111).

5. Uprawnienia wykonawcze - prezydent mianuje jednego lub więcej wiceprezydentów, premiera, jego zastępców, ministrów i wiceministrów, urzędników cywilnych. Przyjmuje także ich rezygnacje i może ich zdymisjonować. Ponadto zwołuje posiedzenia Rady Ministrów pod swoim przewodnictwem, może żądać raportów od premiera i ministrów. Prezydent ogłasza przeprowadzenie referendów w sprawach ważnych dla państwa, powołuje specjalne ciała, rady i komitety, określając ich uprawnienia i zadania (art. 91, 97, 99, 106, 115, 116).

6. Uprawnienia w stosunku do władzy sądowniczej — prezydent wraz z Najwyższą Radą Sądowniczą dba o niezależność sądownictwa w Syrii, przewodniczy tej Radzie, mianuje przewodniczącego Najwyższego Sądu Konstytucyjnego na mocy dekretu (art. 132, 133, 141).

W opinii syryjskiej opozycji i państw zaangażowanych w rozwiązanie konfliktu konstytucja z 2012 r. powinna zostać zastąpiona inną. Zgodnie z nową propozycją ustawy zasadniczej rola prezydenta miałaby zostać osłabiona kosztem wzmocnienia parlamentu. Wymóg opracowania nowej konstytucji dla Syrii przyjęła Rada Bezpieczeństwa ONZ w rezolucji nr 2254 z 18 grudnia 2015 r. ${ }^{17} \mathrm{~W}$ następnym roku podczas negocjacji genewskich opozycja syryjska zaleciła zawieszenie konstytucji z 2012 r. ${ }^{18}$ Grupa Działania ds. Syrii (Action Group on Syria) ${ }^{19}$ zasugerowała kilka rozwiązań

17 Pkt 4 decyzji nr 2254 (2015) podjętej przez Radę Bezpieczeństwa na posiedzeniu 7588 w dniu 18 grudnia 2015 r., <https://undocs.org/ar>, dostęp 12 VII 2019.

${ }^{18}$ R. Ziadeh, The History of the Syrian Constitution, „Syrian Studies Association Bulletin” 2017, t. 22, nr 1, <https://ojcs.siue.edu>, dostęp 20 VII 2019.

${ }_{19}$ W skład grupy wchodzili przedstawiciele ONZ, Ligi Państw Arabskich, UE, USA, Chin, Francji, Rosji, Wielkiej Brytanii, Turcji, Iraku, Kuwejtu i Kataru. 
ustrojowych. Należy do nich unieważnienie konstytucji z 2012 r. czy przywrócenie postanowień ustawy zasadniczej z 1950 r. na okres przejściowy, ponieważ uchodzi ona za „,pierwszą prawdziwą syryjską konstytucję od odzyskania niepodległości”20, przyjętą przez parlament mający „,prawdziwą powszechną legitymację”. Konstytucja z 1950 r. miałaby być bazą do zmian ${ }^{21}$. W ocenie niektórych badaczy $80 \%$ jej treści można wykorzystać w niezmienionej formie, a pozostałą część zmienić i przyjąć na okres przejściowy do czasu opracowania właściwej konstytucji ${ }^{22}$. Inni z kolei sugerują porzucenie zamysłu aktualizacji ustawy zasadniczej z 1950 r. i przyjęcie deklaracji konstytucyjnej ograniczonej czasowo ${ }^{23}$.

Syryjska opozycja zaproponowała także możliwość nowelizacji obowiązującej ustawy zasadniczej i innych aktów prawnych, idąc w kierunku ograniczenia uprawnień prezydenta, ponieważ jego szerokie prerogatywy podważają zasadę trójpodziału władzy. Ponadto, jak zauważono, niektóre uprawnienia prezydenta są niejasne i zbyt szerokie, co sprawia, że są trudne do zdefiniowania ${ }^{24}$. Dotyczy to np. art. 83, 97, 105, 111, 113-116, 132 konstytucji.

\section{Podsumowanie}

Podsumowując, należy twierdzić, że wraz z przejęciem władzy prezydenckiej w Syrii przez Hafiza al-Asada wprowadzono silne rządy prezydenckie. Inspiracją tych zmian był Gamal Abd al-Nasir - prezydent Egiptu, a później Zjednoczonej Republiki Arabskiej $^{25}$. Na mocy konstytucji z 1973 r. H. al-Asad skupił w swoich rękach władzę absolutną. Nie ponosił odpowiedzialności za naruszenie konstytucji, a jego akty nie wymagały kontrasygnaty odpowiedniego ministra. Ponadto sam mógł zainicjować zmianę konstytucji. Poza uprawnieniami w zakresie władzy ustawodawczej miał także uprawnienia należące do władzy sądowniczej. Silnej władzy prezydenta sprzyjał stan wyjątkowy, który utrzymał się w Syrii do 2011 r. Dawał on głowie państwa możliwość korzystania z dodatkowych uprawnień przysługujących w takich sytuacjach. Uprawnienia te i silna pozycja egzekutywy, w tym prezydenta, zostały zachowane w konstytucji z 2012 r. W 2019 r. mija 48 lat, odkąd władza prezydencka należy do jednej rodziny al-Asadów. Można się zatem zastanowić, czy w Syrii jest system demokratyczny, jak założono w konstytucji, czy może dżumlukijje $e^{26}$, co oznacza republikę monarchiczną lub system rządów autorytarnych, o czym może świadczyć wiele elementów. Do nich

${ }^{20}$ Report Syria Opitions for a Political Transition, July 2015, s. 15, Action Group on Syria, <https:// www.cartercenter.org>, dostęp 12 VII 2019.

${ }_{21}$ Building a Political System for a Future Syria, <http://syrianexperthouse.org>, dostęp 12 VII 2019.

22 Report Syria Opitions..., s. 16.

23 Ibidem, s. 17.

24 Ibidem, s. 4, 10.

25 F. Leverett, Inheriting Syria: Bashar's Trial by Fire, Washington D. C., 2005, s. 26.

26 Jest to sformułowanie arabskie będące skrótem z dwóch słów: dżumhurijja i malakijja, które oznaczają odpowiednio: republika i monarchia. 
można zaliczyć silny autorytet prezydenta, organizacja władzy oparta na zasadzie wodzostwa, brak wolności i praw obywatelskich czy przemoc wobec obywateli ${ }^{27}$. Jednocześnie należy podkreślić, że w muzułmańskiej tradycji nie było miejsca na parlament. Istniała silna władza centralna, której poddani byli podporządkowani. Miało to związek z obowiązkiem religijnym, ponieważ rządzący cieszyli się boskim autorytetem i wymuszali posłuszeństwo wśród ludu.

Podstawą przyszłości ustrojowej Syrii powinien być system demokratyczny oraz zmiana konstytucji, nie tylko jej zapowiedzi, ale przede wszystkim wcielanie w życie i przestrzeganie ujętych w niej zasad przez elity polityczne. Rekonstrukcja ustroju powinna polegać na przejściu do modelu semiprezydenckiego. Prezydent swoją władzą powinien podzielić się nie tylko z rządem, ale także z parlamentem. A ten ostatni powinien być silny, ale jednocześnie odzwierciedlać podziały społeczne, w tym religijne, narodowe i etniczne. Postuluje się także wprowadzenie w Syrii bikameralizmu i konfesjonalno-narodowego systemu rządów (opartego na kluczu wyznaniowym i narodowym). Wprowadzenie zmian będzie jednak trudne z uwagi na brak woli elit do transformacji. Alawici dzierżący władzę nie będą chcieli jej utracić i tym samym mogą blokować reformy. Ponadto syryjska opozycja nie jest silna (m.in. z powodu zaangażowania w konflikt np. Rosji, Iranu, Turcji, USA), a świadomość polityczna obywateli państwa niewielka. Problemem może być także sektarianizm i plemienność, jak również brak politycznej i społecznej stabilności po zakończeniu wojny. By powiodły się zmiany, potrzebna będzie reforma ekonomiczna oraz budowa społeczeństwa obywatelskiego i rozwój partycypacji politycznej społeczeństwa syryjskiego.

\section{Bibliografia}

\section{ŹRÓDŁA}

Decyzja nr 2254 (2015) podjęta przez Radę Bezpieczeństwa na posiedzeniu 7588 w dniu 18 grudnia 2015 r., <https://undocs.org/ar>.

Dekret ustawodawczy 276 z 1969 r. o obywatelstwie syryjskiego Araba wraz z pouczeniem wykonawczym, <http://parliament.gov.sy/arabic>.

Konstytucja Arabskiego Królestwa Syrii z 1920 r. (Konstytucja Wielkiego Królestwa Syrii), $<$ http://emediatc.com>.

Konstytucja państwa syryjskiego z 1930 r., <http://parliament.gov.sy>.

Konstytucja Syrii z 1950 r., <http://dustour.org/media-library>.

Konstytucja Syryjskiej Republiki Arabskiej z 1953 r., <http://parliament.gov.sy>.

Konstytucja Syryjskiej Republiki Arabskiej z 27 lutego 2012 r., <http://www.parliament.gov.sy>. Konstytucja tymczasowa z 1969 r., konstytucja al-Baas, <http://parliament.gov.sy>.

Konstytucja Zjednoczonej Republiki Arabskiej z 1958 r., <http://el-borai.com>.

${ }^{27}$ F. Jomma, Wplyw podziałów religijnych..., s. 361-371. 
Report Syria Opitions for a Political Transition, July 2015, s. 15, Action Group on Syria, $<$ https://www.cartercenter.org $>$.

Stała konstytucja syryjska z 1973 r., <http://emediatc.com>.

Tymczasowa konstytucja z 1964 r., <http://souri.net>.

\section{PIŚMIENNICTWO}

Al-dasatir al-mutaakiba fi suria: tahlil we mukarana (Kolejne konstytucje Syrii: analiza porówna$w c z a$, czerwiec 2017 r.), IDRAK Centre for Studies \& Consultations, <https://idraksy.net>. Building a Political System for a Future Syria, <http://syrianexperthouse.org>.

Fildis A.T., The Troubles in Syria: Spawned by French Divide and Rule, ,Middle East Policy Council" t. XVIII, nr 4, https://www.mepc.org, https://doi.org/10.1111/j.1475-4967.2011. 00515.x.

French Mandate for Syria and the Lebanon, „The American Journal of International Law” t. 17, nr 3, Supplement: Official Documents (Jul., 1923), <http://www.ndu.edu.lb>.

Historia państwa i prawa. Wybór tekstów źródłowych, red. B. Lesiński, Wydawnictwo Ars Boni et Aequi, Poznań 1995.

Jomma F., Wpływ podziałów religijnych, narodowych i etnicznych na procesy polityczne w Syrii, Wydawnictwo Uniwersytetu Szczecińskiego, Szczecin 2018.

Kiwan M., Sawabit we mutaghejerat al-dasatir As-surija min 1920 ila 1971, <http://www. alkhaleej.ae>.

Kowalczyk T., Ograniczenia biernego prawa wyborczego na urzad Prezydenta RP, [w:] Wybory $i$ pozycja ustrojowa prezydenta $w$ wybranych państwach świata, red. R. Zych, Wydawnictwo Naukowe Uniwersytetu Mikołaja Kopernika, Torun 2011.

Leverett F., Inheriting Syria: Bashar's Trial by Fire, Brookings Institution Press, Washington D.C., 2005.

Moubayed S.M., Stell \& Silk. Men and Women Who Shaped Syria 1900-2000, Cune Press, Seattle 2006.

Polskie prawo konstytucyjne. Stan prawny na dzień 1 września 1997 r., red. W. Skrzydło, Wydawnictwo MORPOL, Lublin 1997.

Sarnecki P., Prezydent Rzeczypospolitej Polskiej. Komentarz do przepisów, Wydawnictwo Zakamycze, Kraków 2000.

Tsasul tarihi li tatawir al-distor as-suri, The Arab Orient Center for Strategic and Civilization Studies London, 11.02.2013, <https://www.asharqalarabi.org.uk>.

Ziadeh R., The History of the Syrian Constitution, „Syrian Studies Association Bulletin” 2017, t. $22, \mathrm{nr} 1,<\mathrm{https}: / /$ ojcs.siue.edu $>$. 